\title{
Peragaan Penggunaan Meja Instrumen Multifungsi Pemantau Kesehatan Balita di Posyandu
}

\author{
B. S. Rahayu Purwanti ${ }^{1 *}$, Nuralam ${ }^{2}$, Latif Mawardi ${ }^{3}$ \\ 1,2,3Program Studi D-3 Elektronika Industri, Jurusan Teknik Elektro \\ Politeknik Negeri Jakarta \\ *Penulis Korespondensi, B. S. Rahayu Purwanti. Program Studi D-3 Elektronika Industri, Jurusan Teknik Elektro \\ Politeknik Negeri Jakarta, Kampus Baru UI, Depok 16425. Email: rahayu.purwanti@elektro.pnj.ac.id.
}

\begin{abstract}
ABSTRAK
Covid-19 memberlakukan 5M, yaitu Memakai masker, Mencuci tangan pakai sabun dan air mengalir, Menjaga jarak, Menjauhi kerumunan, serta Membatasi mobilisasi dan interaksi. Dua dari 5M, yaitu menjaga jarak dan menjauhi kerumunan sangat ketat diterapkan sampai sekarang, walaupun hampir seluruh masyarakat sudah divaksinasi. Demikian juga para kader Posyandu Rambutan di Blok Tempe, RT6 RW II, Desa Citeureup yang secara rutin memantau kesehatan balita. Pemantauan dilakukan lebih cepat dengan pengukuran berat badan, pengukuran tinggi badan, dan suhu menggunakan tiga alat ukur yang berbeda. Ketiga layanan pengukuran tersebut dapat menimbulkan antrian, akibat alat-alat ukur masih konvensional. Oleh karena itu muncul ide, membuat meja multifungsi dengan tiga macam pengukuran secara otomatis. Selain sebagai alat pengukur suhu, secara bersamaan juga untuk menimbang badan dan mengukur tinggi balita. Selanjutnya, secara spesifik hanya membahas uji alat ukur yaitu memastikan fungsi dari sensor loadcell, LiDAR, dan infrared pada meja instrument. Cara kerja meja instrumen; balita ditidurkan di atas kasur busa. Kaki balita harus menyentuh kayu pembatas di ujung laci meja agar tinggi badan balita dapat terukur. Kasur busa berada di dalam laci meja yang didesain sedemikian rupa sehingga balita aman. Salah satu sisi meja terdapat dinding yang telah dipasang sensor ultrasonik sebagai pengukur tinggi, dan berat badan balita juga dapat diukur pada saat bersamaan. Hal tersebut dikarenakan, bagian bawah penyangga laci dipasang sensor loadcell sebagai penimbang. Laci bagian bawah untuk layanan balita $\leq 12$ bulan atau belum bisa berdiri di atasnya. Sedangkan balita yang usia 12-59 bulan, pemeriksaannya dilakukan di bagian sisi dinding kompartemen. Hasil pengukuran pada alat dapat ditampilkan di Liquid Crystal Display (LCD) data hasil deteksi tiga sensor. Kader dapat melakukan pengukuran suhu tubuh balita $\left({ }^{\circ} \mathrm{C}\right)$, berat badan $(\mathrm{kg})$, dan tinggi badan $(\mathrm{cm})$ menggunakan meja instrument dengan mengikuti petunjuk pengunaannya. Booklet yang memuat petunjuk penggunaan sesuai tahap pengukuran, dipasang di sisi depan dinding meja instrument.
\end{abstract}

Kata Kunci: Balita, Berat, Pengukur, Sensor, Tinggi.

\begin{abstract}
The 5M covid-19 rule are wearing mask, washing hands, keeping distance, avoiding crowd, and limiting mobilization movements. Both of the 5M still strictly apply until now are social distance, avoiding crowd, even most of all public were vaccinated. As well. the cadres of Posyandu Rambutan at Blok Tempe RT6 RW II, Citeureup, who regularly monitor for toddler health. The toddler health monitoring with measurement of weight, height, and body temperature. That's the three services measurements could made the queue, caused the measurement tools still a conventional. Therefore, come up an idea for made the table multifunction with three kinds of measurement. Beside as the temperature measurement, also for weight and height for toddler. And then, a specific topic is discussing to make sure the measurement device test, are sensors function of loadcell, LiDAR, and infrared at the measurement table. The procedure of table instrument, that's are the toddler put to sleep on a mattress. The toddler's feet have to touch the barrier woods, so that measurable his height. The metres in the measurement table of drawer designed in such a way that the toddler is safe. One side of the table, there is wall that has been installed for height measuring device, and weight also was measured at the same time. This is because the bottom of drawer holder was installed a loadcell sensor.
\end{abstract}




\section{VIVABIO}

Jurnal Pengabdian Multidisiplin
Volume 3 Nomor 3, [ Desember 2021] hal 9-15 ISSN 2685-1091

DOI: https://doi.org/10.35799/vivabio.v3i3.35936

Bottom of drawer for services the toddler with age $<12$ months or who can't stand on it. However, the toddlers age ( $\leq 59$ months the check-up are doing at the side of compartment wall. The measurement results can be displayed in Liquid Crystal Display ( $L C D)$ were data of three kind of result detection. The measurement of body temperature $\left({ }^{\circ} \mathrm{C}\right)$, weight $(\mathrm{kg})$, height $(\mathrm{cm})$ has made a booklet for instrument table's user. Cadres did measurements the body temperature $\left({ }^{\circ} \mathrm{C}\right)$, weight $(\mathrm{kg})$, and height use the instrument table by following the instruction for use. Booklet which contains instruction for use according to the measurement steps, installed on the front side off the instrument table wall.

Keywords: Height, Measurement, Sensor, Toddler, Weight

\section{PENDAHULUAN}

\section{Analisis Situasi}

Akhir-akhir ini pelaksanaan, pemantauan protokol kesehatan (prokes) makin digalakkan, dalam upaya preventif penyebaran covid-19. Aspek penting mitigasi bencana dengan mengurangi penyebaran covid19 (Eka Safitrii, Evi Widowati. 2021), melaksanakan 3M;yaitu Mencuci tangan, Menggunakan masker, Membatasi jarak, dan lebih aman lagi 5M. Dua M berikutnya adalah Menghindari kerumunan dan Membatasi mobilitas termasuk di tempat kerja, Metode pelaksanaannya dengan antisipasi penyebaran kasus terinfeksi dan kematian atau (mitigasi dengan menyediakan persiapan yang memadai (Chan, D. W.-K. 2020). Selain prokes, meningkatkan imun tubuh, juga dengan rutinitas pemeriksaan Kesehatan, pembuatan sarana pelindung atau pencegah penyebaran virus.

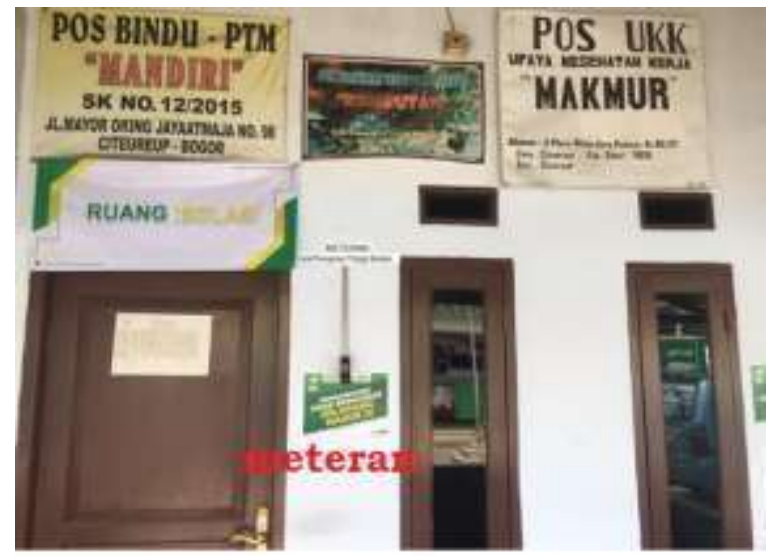

Gambar 1 Area Kegiatan Posyandu Rambutan di depan Pos Keamanan

Pelaksanaan kegiatan posyandu Rambutan memanfaatkan area parkir di depan Balaidesa dan teras pos LinMas. Kegiatan Posyandu Rambutan sebelum dan sesudah masa covid-19, dilakukan dengan cara berbeda. Hal tersebut mengingat lokasi sempit dengan area gerak yang sangat terbatas ( Gambar 1 ).

Keterbatasan ruang atau area pelaksanaan Posyandu Rambutan tidak memungkinkan diperluas guna memaksimalkan area posyandu. Kerapihan dan kebersihan di Pos Keamanan sudah memadai dan perlu dipertahankan. Alasan pemilihan topik/judul adalah; (a) rutinitas kegiatan posyandu Rambutan, (b) Pelaksana posyandu (para kader), dan balita serta pengantarnya harus tetap patuh pada prokes, (c) Minimalisasi ruang gerak dan optimasi peralatan.

Ketentuan terkait dengan keberlanjutan kegiatan Pengabdian Masyarakat (Pengmas) yang didanai P3M PNJ, Prodi D-3 EI juga telah melaksanakan survey ke masyarakat Blok Tempe. Topik yang diangkat dalam Pengmas Berbasis Prodi tahun 2021 masih berkisar pada upaya dan kontribusi warga dalam menjaga Kesehatan. Khususnya kegiatan di Posyandu dan terkait dengan penggunaan alat ukur dalam satu kali tindakan di ruang terbatas.

Berdasarkan permasalahan sempitnya area kegiatan Posyandu dan gencarnya antisipasi penyebaran muncul gagasan untuk membuat alat dan sistem pada ruang terbatas, tetapi bisa dilaksanakan pada saat bersaman. Pada waktu hampir bersamaam dapat diukur suhu, Berat Badan (BB), dan Tinggi Badan (TB) di dalam satu Meja Instrumen.

\section{Tujuan dan Manfaat Kegiatan}

Sesuai dengan rencana kegiatan, maka luaran yang dihasilkan atau ditargetkan dalam kegiatan pengabdian kepada masyarakat ini adalah:

a. Merancang bangun meja instrumen untuk mengukur/mendeteksi suhu $\left({ }^{\circ} \mathrm{C}\right)$ tubuh, berat badan $(\mathrm{kg})$ balita, dan tinggi badan $(\mathrm{cm})$ balita; 


\section{VIVABIO}

Jurnal Pengabdian Multidisiplin

b. Mengenalkan penggunaan alat ukur dengan teknologi pada meja multifungsi,

c. Memberdayakan kader Posyandu Blok Tempe untuk layanan pengukuraan kesehatan berbasis teknologi tepat guna, dan pengawasan kesehatan balita di Posyandu.

\section{METODE PELAKSANAAN}

\section{Sasaran kegiatan}

Yang menjadi sasaran pelaksanaan kegiatan pendampingan adalah kader Posyandu untuk operasional penggunaan Meja Instrumen. Selain itu untuk pemantauan fungsi Meja Instrumen Posyandu memberdayakan Kelompok Remaja Blok Tempe (RBT) untuk pemeliharaan dan perbaikan.

\section{Lokasi kegiatan}

Pengabdian kepada Masyarakat adalah Kader dan balita di Posyandu Rambutan, RT.06/ RWXII, Blok Tempe, Desa Citeureup,

Kabupaten Bogor, Jawa Barat.

Metode yang digunakan : Adapun beberapa metode yang digunakan dalam Pengabdian kepada Masyarakat adalah:

a) Studi Literatur yang berkaitan dengan tata cara pelaksanaan layanan di Posyandu

b) Instalasi modul-modul pengukur pada Meja Instrumen sesuai fungsi dan teori/prosedur.

c) Metode penerapan teknologi tepat guna bagi mayarakat,

d) Memberi pendampingan kepada ketua kader posyandu untuk penggunaan Meja Instrumen Pemantau Kesehatan Balita.

Produk Pengabdian kepada Masyarakat dikerjakan dengan beberapa tahapan kegiatan. Metode penyelesaian masalah dengan membuat alat/sistem tepat guna dengan sasaran/target kegiatan adalah pemberdayaaan kader Posyandu. Obyek kegiatan Pengabdian Masyarakat diberdayaakan untuk optimasi layanan posyandu berbasis teknologi. Sebagian tahapan dilaksanakn dengan cara Research and Development (R\&D), yaitu peracangan dan perakitan alat ukur. Fungsi alat ukur untuk memantau Kesehatan balita dengan pengukuran BB dan TB pada satu Meja Instrumen menyerupai box, saat tertutup. Saat laci dan atau kompartemen Meja Instrumen terbuka dan
Volume 3 Nomor 3, [ Desember 2021] hal 9-15 ISSN 2685-1091

DOI: https://doi.org/10.35799/vivabio.v3i3.35936

dapat dilihat tiga alat ukur yang berbeda kegunaannya. Sensor infrared t MLX90614 dikalibrasi dengan hermometer, sebagai pendeteksi suhu tubuh. Perangkat pengatur, pemroses data adalah mikrokontroller dan LCD sebagai tampilan hasil deteksi tiga sensor.

Uji kelayakan fuksi alat ukur pada sampel balita dan anak-anak 1 tahun $\leq$ usia $<5$ tahun, operator pengukur ketua Posyandu. Waktu uji fungsi 0810 September 2021, untuk memastikan fungsi alat sesuai rencana.

Alat pengukur suhu tubuh bervariasi jenis dan metode penggunaannya. Termometer analog, digital sudah dikenal oleh khalayak. Namun, akhir-akhir ini timbul kekhawatiran infeksi nosokomial (Sued BPR, Pereira PMA. et al. 2017), akibat kontak langsung alat ukur dengan tubuh (Adrianto 2018). Termometer tersebut dikhawatirkan sebagai media penyebaran bakteri/virus dari satu pasien ke pasien (Meilia Safitri, Gusti Arya Dinata. 2019) dengan satu thermometer yang sama.

\section{HASIL DAN PEMBAHASAN}

Hasil kegiatan pengabdian masyarakat yang diperoleh melalui tahapan berikut:

\section{Studi Literatur}

Alat pengukur suhu tubuh tanpa kontak fisik didesain oleh (Steven J. 2016), diuji pada 4 orang pasien, pengambilan data sebanyak 5 kali per pasien. Kalibrasi data ukur dengan membandingkan hasil deteksi sensor dan termometer digital terkalibrasi. Ilustrasi Perhitungan Jarak dengan Metode Euclidean Distance (MRD). Hhasil ukur dari sensor dibandingkan dengan jaarak dari hasil perhitungan. Perhitungan jarak dengan MED persamaan berikut. Metode pengukuran pemetaan dengan perhitungan dan penggambaran suatu objek dari hasil rekam data softcopy dan hardcopy (B. A. A. B. Sinajujung. 2017). Metode Euclidean Distance (MED) untuk mengukur jarak antara dua titik (A. K. C. V. A. Rezky Rizaldi. 20218) berbeda dengan menarik garis lurus di antara kedua titiknya. Pengukur jarak antar objek yang terdeteksi dalam suatu ruangan dengan memetakan beberapa titik sebagai ilustrasi Euclidean Distance.

Sensor ultrasonik untuk mengukur jarak dari hasil konversi waktu tempuh sinar datang- 


\section{VIVABIO}

Jurnal Pengabdian Multidisiplin

balik yang memancar pada gelombang ultrasonic. Trigger sensor diperoleh dari transmitter sinyal yang diterima balik oleh receiver ( echo) sebagai hasil sinyal pantulan objek. Jarak objek merupakan representasi dari waktu pancar dan waktu terima gelombang ultrasonik ( Nurlette, D. dan Toni Kusuma W, 2018 ).

Beberapa penelitian sebelumnya tentang Light Detection and Ranging (LiDAR) berkaitan dengan pemetaan dan pendeteksian objek (A. P. W. N. B. Aisah Hajar. 2017). Deteksi objek yang dihasilkan kurang inheren, jumlah data yang terdeteksi tidak tepat. Pendeteksi objek dengan sensor ground-based LiDAR pada jarak ukur $>6 \mathrm{~m}$ dan berputar $360^{\circ}$ (B. A. A. B. Senanjung. 2017).

Gain menguatkan output sensor Loadcell sebesar VR (Deddy Hardianto, Sigit Priyambodo, S.T. M.T, Ir. Muhammad Suyanto, M.T. 2014) dikoneksikan ke rangkaian penguat sensor untuk menaikkan tegangan output. Fungsinya sebagai penguat tegangan pin input ACD pada mikrokontroler ( bertegangan rendah, 3 volt ) atau kalibrator. Penguat tegangan output mikrokontroler sangat rendah.

\section{Kegiatan di Posyandu}

Istilah Pos Pelayanan Terpadu (Posyandu) dan proses peninbangan (Tri Hamdani Agung Cahyono1\&Eko Agus Suprayitno. 2018) oleh kader dilakukan secara manual. Kader mencatat hasil penimbangan balita sesuai skala pada timbangan gantung, biasanya untuk menimbang beras, atau benda lain dengan posisi digantung. Potensi kesalahan sangat besar dalam melihat garis skala pada timbangan oleh kader (human error), oleh karena itu dikembangkan penggunaan sensor.

\section{Perencanaan Alat Ukur}

Desain alat/sistem pengabdian kepada masyarakat Berbasis Prodi ini mengadopsi konsep penelitian (Tri Hamdani Agung, Cahyono \& Eko Agus Suprayitno. 2018). Desain alat mengacu pada Blok Diagram (Gambar 2), perbedaanya pada outputnya, dalam kegiatan Pengmas menggunakan LCD dengan komunikasi serial.
Volume 3 Nomor 3, [ Desember 2021] hal 9-15 ISSN 2685-1091

DOI: https://doi.org/10.35799/vivabio.v3i3.35936

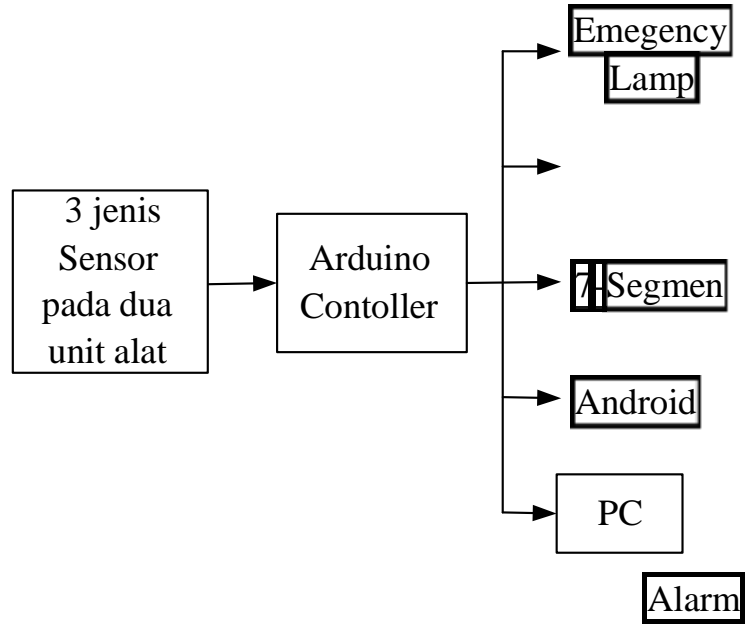

Gambar 2 Blok Diagram Alat

Kesamaan konsep yaitu menggunakan tiga sensor untuk mengukur suhu, BB, TB sebagai kegiatan pemantauan Kesehatan balita di Posyandu. Alur berfikir sistem (Gambar 3), cara kerja keseluruhan alat.

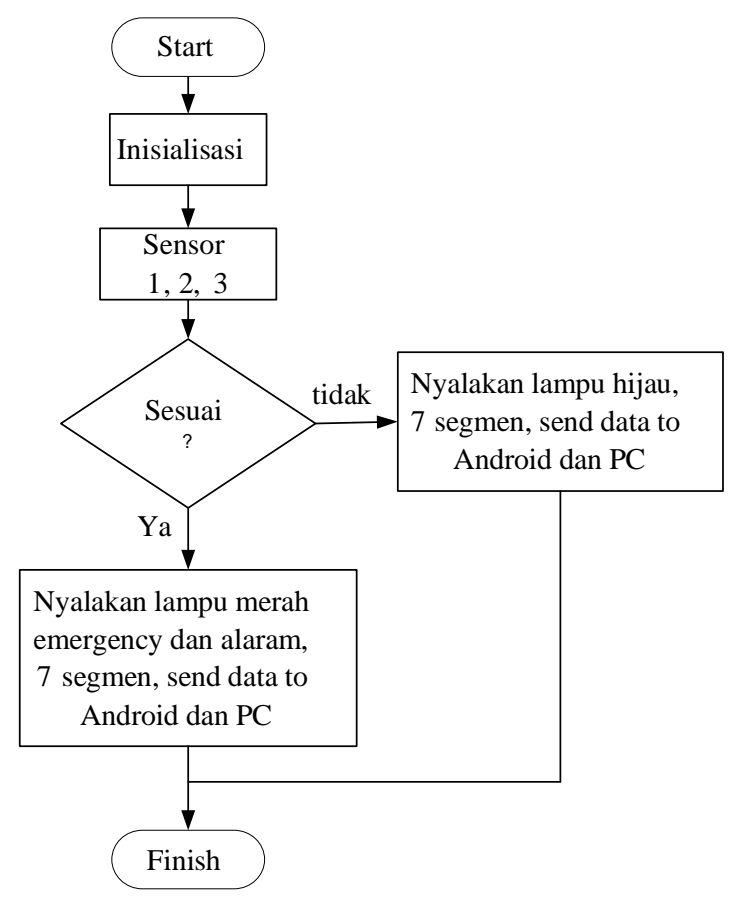

Gambar 3 Flowchart Program

\section{Pengujian Fungsi Elektri}

Kelebihan desain pada alat selain sensor suhu menggunakan sensor LiDAR, tidak terganggu saat obyek ukur goyang akibat terdorong/bergeser. Selain itu seluruh modul ukur dipasang pada laci dan kompartemen satu box, meyerupai lemari. 


\section{VIVABIO}

Jurnal Pengabdian Multidisiplin
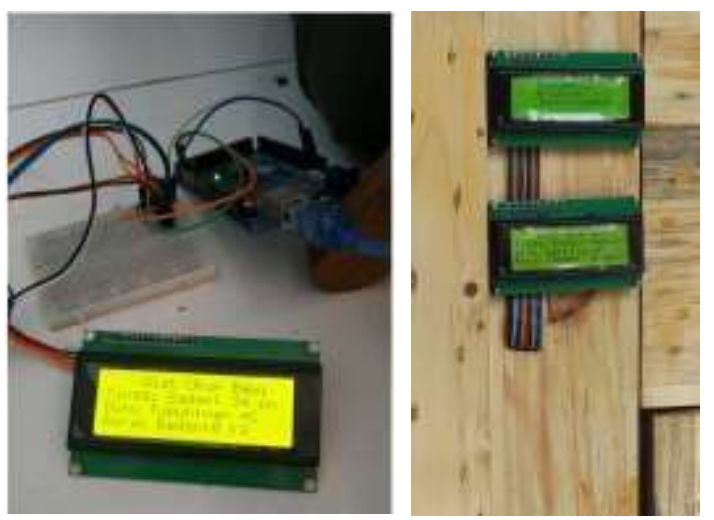

Gambar 4 Uji Fungsi LCD ( kiri ), LCD sebagai Penampil Data Ukur ( kanan )

\section{Redesain Meja Instrumen}

Kendala di awal untuk merealisasikan desain meja instrument multifungsi adalah tidak dimengerti oleh tukang mebel Desain Meja Instrumen yang dilengkapi alat ukur menggunakan sistem digital (Gambar 4). Sehingga perlu diperbaiki, agar detil setiap sisi terlihat dan berfungsi sistem penukurannya. Pendapat calon pembuat meja, bahwa desain meja yang dirancang tergolong rumit. Oleh karena itu harus costume. Berdasarkan kendala desain dimaksud, dibuatlah tampak gambar sesuai partisis dan kompartemen sesuai dengan dimensi meja instrumen.

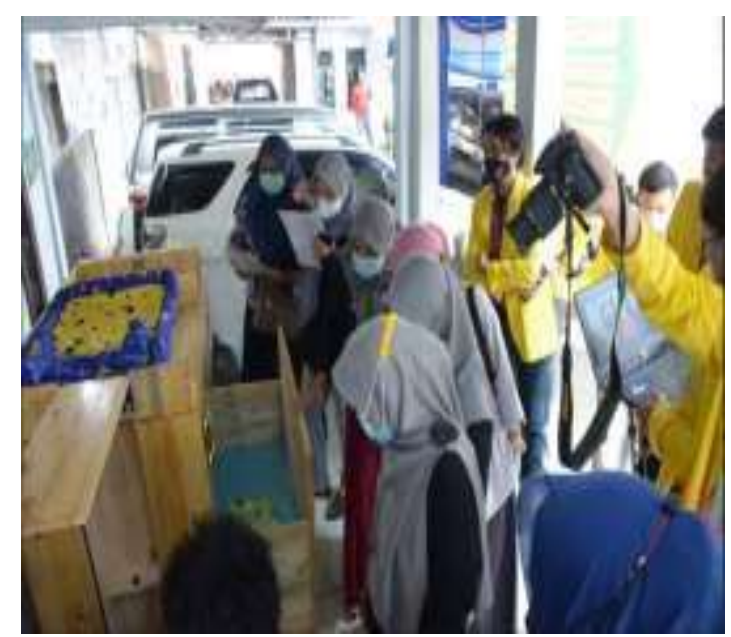

Gambar 5 Kader Posyandu menyaksikan Laci Meja Instrumen Multifungsi

Laci atas untuk menyimpan peralatan/ kelengkapan pelaksanan posyandu. Laci bawah dilengakapi kasur balita $<1$ tahun, $(<12$
Volume 3 Nomor 3, [ Desember 2021] hal 9-15 ISSN 2685-1091 DOI: $\underline{\text { https://doi.org/10.35799/vivabio.v3i3.35936 }}$

bulan0 balita ditidurkan di atas kasur untuk diukur BB, TB, dan suhu badannya.

Kompartemen di salah satu dinding Meja Instrumen, untuk mengukur suhu, sensor berhadapan dengan yang diukur. Sensor berada tepat di atas kepala balita $\geq 1$ tahun dan $\leq 59$ bulan untuk mengukur tinggi badan.

Laci dapat dibuka ke atas, demikian juga bagian bawah dibuka kea rah bawa. Bagian yang terbuka ke bawah menjadi pijakan untuk mengukur berat badan. Sedangkan bagian yang terbuka ke atas untuk mengukur tinggi badan (Gambar 5), telah didemosntrasikan di depan para kader Posyandu Rambutan.

\section{Penempatan Modul Ukur}

Demonstrasi penggunaan meja instrumen juga melibatkan mahasiswa (Gambar 6), selain untuk melatih kemandirian juga menambah wawasan teknologi tepat guna bagi mayarakat. Dosen dan mahasiswa datang ke Blok Tempe (Gambar 7) secara offline, bersamaan sebagai tim Pengmas Prodi D3EI, Jurusan Teknik Elektro, PNJ.

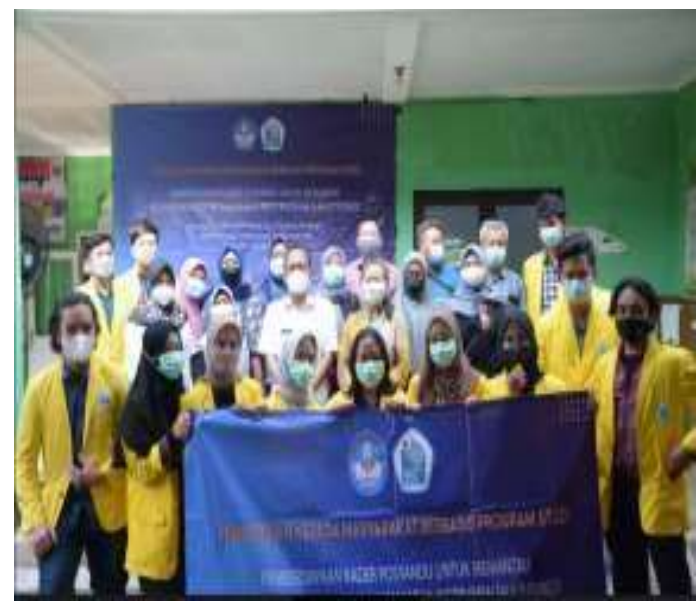

Gambar 7 Tim Pengmas bersama Mahasiswa

Sebagian peserta pengabdian masyarakat yang tidak hadir dapat menyaksikan pelaksanan secara online (Gambar 8). Selain itu, kegiatan pengabdian kepada masyarakat. 


\section{VIVABIO}

Jurnal Pengabdian Multidisiplin

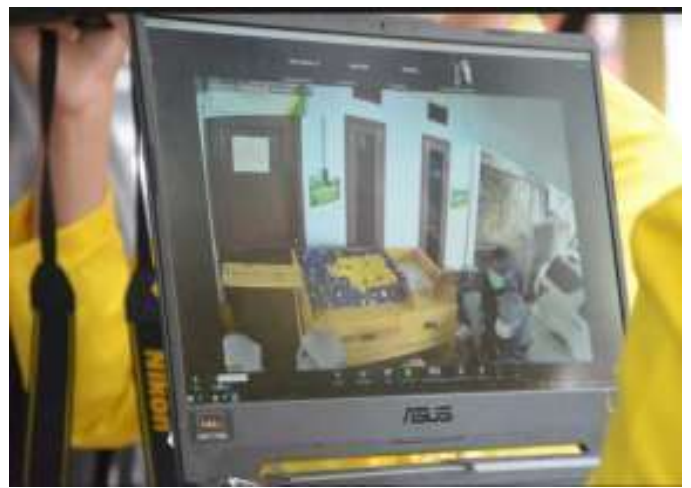

Gambar 8 Tayang Online Melalui Room Zoom bagi Dosen/Mahasiswa

Serah terima meja instrument multifungsi juga telah dilaksanakan pada Kamis, 23 September 2021 (Gambar 9). Dokumen Berita Acara serah terima ditandatangani oleh kedua belah pihak, yaitu ketua Pelaksana Pengmas dan Ketua Kader Posyandu Rambutan. Selain itu, berita pelaksanan Pengabdian kepada Masyarakat dalam bentuk sosialisasi penggunaan meja instrumen multi fungsi telah dipublikasi ke media cetak Radar Depok (Gambar 10).

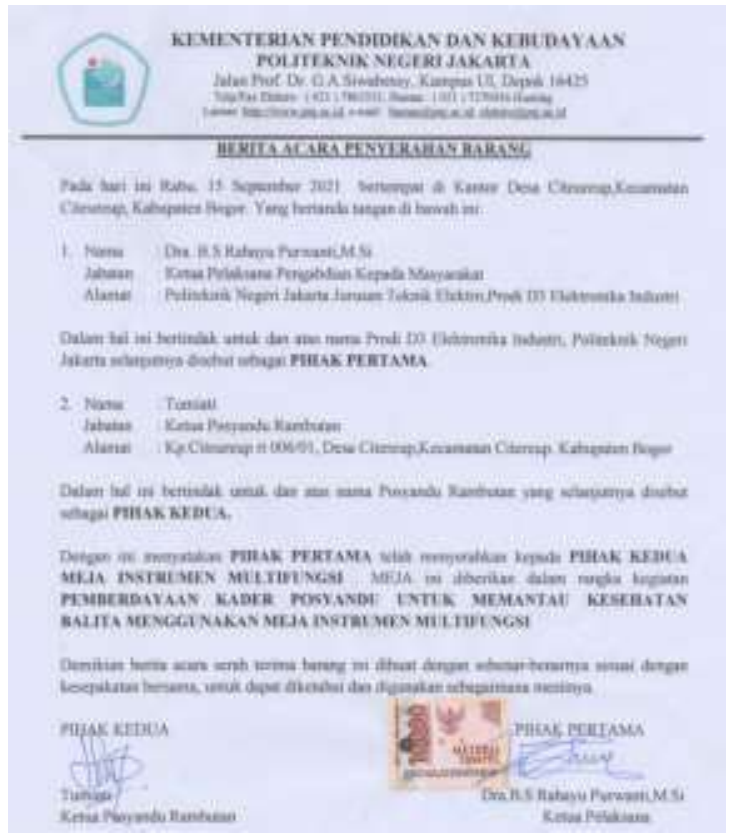

Gambar 8 Berita Acara Serah Terima Meja Instrumen Multifungsi
Volume 3 Nomor 3, [ Desember 2021] hal 9-15 ISSN 2685-1091 DOI: https://doi.org/10.35799/vivabio.v3i3.35936
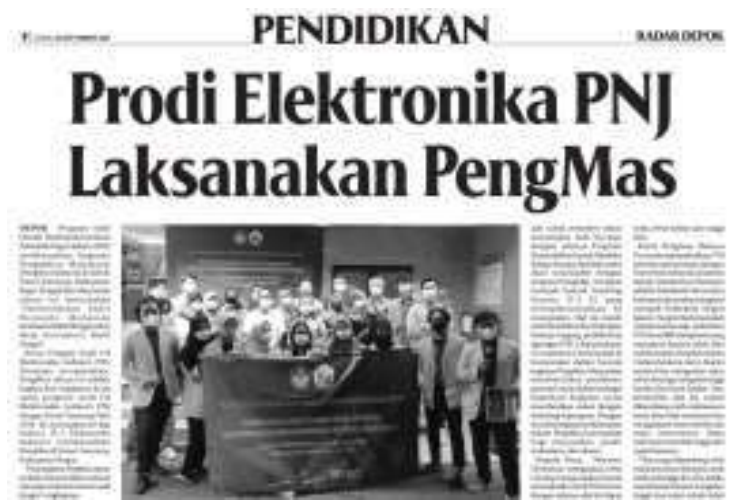

Gambar 10 Publikasi Pengabdian Masyarakat di Media Sosial di Radar Bogor

Kepala Desa Citeureup, Bapak Marwan sangat berharap agar kegiatan Pengmas Prodi berlanjut. Ucapan terima kasih juga disampaikan karena para Dosen dan mahasiswa telah melaksanakan kegiatan sejak tahun 2019-2021 dengan memberi manfaat kepada warga Blok Tempe.

\section{KESIMPULAN DAN SARAN}

Demonstrasi penggunaan Meja Instrumen Multi Fungsi kepada kader-kader Posyandu telah terlaksana. Antusiasme kader terlihat pada permintaan jadwal bersamaan dengan waktu penimbangan balita bulan Oktober. Kegiatan/ program lanjutan dari Pengabdian Masyarakt Tahun 2021 untuk Prodi D-3 Elektronika Industri, Jurusan Teknik Elektro, Politeknik Negeri Jakarta. Kegiatan pendampingan kepada kader dalam upaya pemberdayaan penggunaan Meja Instrumen dalam Kader untuk layanan Posyandu sebagai program berkelanjutan..

\section{UCAPAN TERIMAKASIH}

Terimakasih diucapkan kepada Unit Penelitian dan Pengabdian Masyarakat, Politeknik Negeri Jakarta, yang telah mendanai terselenggaranya Pengabdian Masyaraket Berbasis Program Studi untuk Program Studi D-3 Elektronika Industri, PNJ.

\section{DAFTAR PUSTAKA}

Adrianto AA, Basyar E., 2018. Kesesuaian Termometer Inframerah dengan Termometer Digital terhadap Pengukuran Suhu Aksila pada Usia Dewasa Muda. 


\section{VIVABIO}

Jurnal Pengabdian Multidisiplin

Jural Kedokteran Diponegoro, 7(2): 10411048.

A. K. C. V. A. Rezky Rizaldi, 2018. Implementasi Metode Euclidean Distance untuk Rekomendasi, Jurnal Teknologi Informasi dan Ilmu Komputer (JTIIK), 5(2): 129-138.

P. W. N. B. Aisah Hajar, 2017. Pemanfaatan Lidar untuk Evaluasi Ketinggian, Jurnal. Geodesi Undip, 6(4): 361-370

A. A. B. Senanjung, 2017. Sistem Pemetaan Ruangan 2D Menggunakan Lidar, Jurnal Integrasi 9(1): 73-39.

Chan, D. W. K., 2020. A reflection on the AntiEpidemic Response of COVID-19 from the Perspective of Disaster Management. International Journal of Nursing Science, 382-385.

Deddy Hardianto, Sigit Priyambodo,S.T., M.T, Ir., Muhammad Suyanto, M.T., 2014. Aplikasi Pengukuran Tinggi Dan Berat Badan Menggunakan Output Suara Berbasis ATMEGA16. Jurnal Elektrikal, 1(1): 9-13.

Eka Safitrii, Evi Widowati, 2021. Implementasi Pencegahan dan Mitigasi Covid-19 di PT. Pelindo III Cabang Tanjung Emas Semarang. Indonesian Journal of Public Health and Nutrition (IJPHN Indonesia, UNNES. 1(2): 204-213).

Fauzi, N. A., Hapsari, G. I., \& Rosmiati, M., https://openlibrarypublications.telkomuni versity.ac.id/index.php/appliedscience/art icle/view/11089. (akses 13 Juli 2021)

H. Vardhan and N. K. Pandey. https://open library.telkomuniversity.ac.id/Pustaka. (akses 10 Agustus 2021)

K. Krishan. https://pubmed.ncbi.nlm.nih.gov/ 18515026 (akses 12 Sepember 2021).

M. A. Markom, A. H. Adom, E. S. M. M. Tan, S. A. A. Shukor, N. A. Rahim dan A. Y. M. Shakaff dalam Erdy Sulino. https:// scholar.google.com. (akses 10 September 2021).

Meilia Safitri, Gusti Arya Dinata, 2019 NonContact Thermometer Berbasis Infra Merah. Jurnal Simetris, 10(1): 21-26.
Volume 3 Nomor 3, [ Desember 2021] hal 9-15 ISSN 2685-1091 DOI: https://doi.org/10.35799/vivabio.v3i3.35936

Muhamad Ichwan Sudibyo, Hurriyatul Fitriyah, Rizal Maulana. 2019. Alat Pengukur Berat Badan dan Tinggi Badan Terkomputerisasi berbasis Wireless, Arduino, Sensor Load Cell,dan Ultrasonic. Jurnal Pengembangan Teknologi Informasi dan Ilmu Komputer. 3(9): 8351-8360.

Muhammad Afdali, M. D., 2017. Perancangan Alat Ukur Digital untuk Tinggi dan Berat Badan dengan Output Suara Berbasis Arduino Uno. Jurnal Elkomika Vol. 5(1): $106-118$. ISSN (p): 2338-8323, ISSN (e): 2459-9638.

Saharuddin R. Sokku, Sabran F Harun, 2019. Deteksi Sapi Sehat Berdasarkan Suhu Tubuh Berbasis Sensor MLX90614 dan Mikrokontroller, Prosiding Seminar Nasional LP2M UNM, 613-617. ISBN: 978-623.

Nurlette, D., \& Wijaya, T. K. 2018. Perancangan Alat Pengukur Tinggi dan Berat Badan Ideal Berbasis Arduino. Sigma Teknika, 1(2): 172-184.

Steven J, Zebua D, Suraatmadja MS, Qurthobi A. https://openlibrary.telkomuniversity. ac.id/pustaka. (akses 20 September 2021).

Sued BPR, Pereira PMA, Faria YV, Ramos JN, Binatti VB, dos Santos KRN, 2017. Sphygmomanometers and thermometers as potential fomites of Staphylococcus haemolyticus: Biofilm formation in the presence of antibiotics. MEM Inst. Oswaldo Cruz, 112 (3): 188-195.

Tandini Ulfa Urbach, Wildian. 2019. Rancang Bangun Sistem. Monitoring dan Kontrol Temperatur Pemanasan Zat Cair Menggunakan Sensor Inframerah MLX90614. Jurnal Fisika Unan: 8(3): 273-280.

Tri Hamdani Agung Cahyono \& Eko Agus Suprayitno, 2018. Alat Ukur Berat Badan, Tinggi Badan dan Suhu Badan di Posyandu Berbasis Android. Elinvo (Electronics, Informatics, and Vocational Education), 3(1): 31-38. ISSN 2580-6424 (printed). 